\title{
Physicochemical, Antioxidant and Sensory Quality of Brazilian Blueberry Wine
}

\author{
ROBERTA O. SANTOS, SIMONE C. TRINDADE, LUANA H. MAURER, ANDRIELY \\ M. BERSCH, CLAUDIA K. SAUTTER and NEIDI G. PENNA \\ Departamento de Ciência e Tecnologia de Alimentos, Universidade Federal de Santa \\ Maria/ UFSM, Av. Roraima, 1000, 97105-900 Santa Maria, RS, Brasil \\ Manuscript received on September 29, 2014; accepted for publication on March 11, 2016
}

\begin{abstract}
Currently, Rio Grande do Sul state is the main producer of blueberry in Brazil. Practically all production is commercialized in fresh state and only a small portion is subject to processing. The blueberry wine making process is an alternative to expand the beverage industry and offers to the consumer a value-added product as well as a new market for Brazilian blueberry producers. The objectives of this study were to produce wines from blueberries and to evaluate the effect of deacidification (with calcium carbonate) and chaptalization (with glucose syrup or sucrose) on physicochemical characteristics, antioxidant content, and sensory parameters. Samples were analyzed for total soluble solids, $\mathrm{pH}$, total titratable acidity, total sugar content, alcohol content, monomeric and total anthocyanin, total flavonols, total phenolic compounds and antioxidant activity by DPPH and FRAP methods. The use of calcium carbonate caused a reduction in total titratable acidity, while the use of glucose syrup resulted in wines with low alcohol content. The blueberries wine from Climax and Aliceblue cultivars had higher content of anthocyanin when produced with glucose syrup. The use of calcium carbonate and glucose syrup also provided wines more appreciated by tasters in relation to color. With regard to flavor, George and Aliceblue were the cultivars with lower preference under the control treatments (without carbonate and sugar). The presence of phenolic compounds may have provided a positive influence on wine flavor, once the more preferred wines presented the greater phenolic content.
\end{abstract}

Key-words: Vaccinium ashei Reade, anthocyanin, phenolic compounds, alcoholic beverage.

\section{INTRODUCTION}

Blueberries (Vaccinium sp.) are temperate fruits which require some winter chilling (Allemann and Young 2006). Native in several regions of Europe and the United States, blueberries were first introduced in Brazil in 1983 through a plant collection brought to Embrapa Clima Temperado (Pelotas, RS). Currently, Rio Grande do Sul is the main state in blueberry production in Brazil, with 45 growers cultivating 65 ha and 150 ton (Fachinello 2008). Itaara city is located in the center of Rio Grande do Sul state, at $425 \mathrm{~m}$ of elevation

Correspondence to: Roberta Oliveira Santos

E-mail: roberta.santos@mail.ufsm.br 
above sea level. This climate is favorable for blueberries, with sufficient chilling hours, hard winters and dry summer (Itaaras's City Hall 2010).

Researchers from the Federal University of Rio Grande do Sul (UFRGS) found that the blueberry produced in Brazil has the same characteristics of the fruit cultivated in the United States and Europe, having the same antioxidant characteristics (Fachinello 2008). The antioxidant activity of this fruit is based on high content of phenolic compounds (Ehlenfeldt and Prior 2001, Castrejón et al. 2008) like anthocyanin, phenolic acids and tannins (Mcghie and Walton 2007). These compounds are a current interest due to their important biological and pharmacological properties including antioxidant, antimutagenic, anticarcinogenic, anti-inflamatory, and antiproliferative activities (Kim and Um 2011).

During wine processing, the fruits are pressed to release the sweet juice used for fermentation along with their skins and seeds. Like red grapes, anthocyanins of blueberries are present mainly in the skins (Riihinen et al. 2008), while tannins and phenolic acids predominate in the seeds. During fermentation process, these compounds are transferred to wine and contribute to the color, mouthfeel, and antioxidant properties of the wine.

Despite the similarity with grapes, some varieties of blueberries have less sugar and different organic acid composition, since the main acids in blueberries are both citric and malic acid (Dharmadhikari 1996). Although these acids can be used in acidification to enhance the total acidity of wines, they have an aggressive citric flavor. In order to reduce the acidity in a wine, potassium bicarbonate or calcium carbonate can be used (Jackson 2008). These additives reduce the acidity and increase the $\mathrm{pH}$, in spite of this, they should not be used in high doses because they may lead to problems in stabilization (Rizzon and Gasparin 2005).

Based on these aspects, the aim of this work was to produce wine from blueberries cultivated in Brazil and study the effects of the deacidification and chaptalization on antioxidant, physicochemical and sensory parameters in the blueberry wines produced.

\section{MATERIALS AND METHODS}

\section{SAMPLES AND FERMENTATION}

Blueberries Aliceblue, Climax, and George cultivars (Vaccinium ashei Reade) from Itaara, RS, Brazil were cultivated at the same location (-29 $\left.36^{\prime} 1.31^{\prime \prime},-53^{\circ} 49^{\prime} 6.67^{\prime \prime}\right)$ under the same environmental conditions and harvested at commercially mature stage from different plants, in December 2012. After harvest, fruits were immediately transported to laboratory where they were stored at $18{ }^{\circ} \mathrm{C}$ during 12 hours until use. For each fermentation unit, about $0.7 \mathrm{~kg}$ of fresh blueberries were used, which were divided into five lots. Each lot was treated by adding two types of sugar for chaptalization and calcium carbonate for deacidification as follows: (T1) control without sucrose and $\mathrm{CaCO}_{3}$, (T2) sucrose $+0.9 \mathrm{~g} \mathrm{~L}^{-1} \mathrm{CaCO}_{3}$, (T3) sucrose $+1.8 \mathrm{~g} \mathrm{~L}^{-1}$ $\mathrm{CaCO}_{3}$, (T4) glucose syrup $+0.9 \mathrm{~g} \mathrm{~L}^{-1} \mathrm{CaCO}_{3}$, (T5) glucose syrup $+1.8 \mathrm{~g} \mathrm{~L}^{-1} \mathrm{CaCO}_{3}$.

In order to adjust the level of sugar in the blueberry must, $30 \mathrm{~g} \mathrm{~L}^{-1}$ of sugar previously set was added with the aim of increasing the alcohol content in $1.5 \%$ after fermentation, value allowed by legislation.

The experiment was guided with 3 cultivars, 2 types of sugar and 2 doses of carbonate with 3 repetitions, using the experimental outline totally randomized in a factorial scheme $3 \times 2 \times 2$. After crushed, pectinolytic enzyme $\left(3.5 \mathrm{~g} \mathrm{hL}^{-1}\right)$ was added to the blueberry must and commercial yeast was inoculated (Saccharomyces cerevisiae, $20 \mathrm{~g} \mathrm{hL}^{-1}$ ). The maceration was carried out with skins and seeds for 12 days and total soluble solid content was checked periodically. The room temperature was maintained at $22 \pm 2{ }^{\circ} \mathrm{C}$. When the 
fermentation process was completed, a $50 \mathrm{ppm}$ solution of sulphur dioxide was added. All treatments were made in triplicate.

\section{PREPARATION OF EXTRACTS}

Ten grams of blueberries from each cultivar were blended with $20 \mathrm{~mL}$ of distilled water and centrifuged (10 min, $1559.6 \mathrm{~g}$ ). The supernatant was collected in order to determine $\mathrm{pH}$, total titratable acidity and sugar content. The same procedure was used to determine total and monomeric anthocyanins, total flavonol and phenolic content. However, $70 \%$ ethanol acidified with $0.1 \%$ hydrochloric acid was used as extractor solvent.

Total Soluble Solids, pH, Total Titratable Acidity, Total Sugar Content AND Alcohol Content

The total soluble solids (TSS) was measured in fruits with refractometer (Biobrix ${ }^{\circledR}$ ) and expressed in ${ }^{\circ}$ Brix. A pH meter $\left(\right.$ Digimed $^{\circledR}$ ) was used to measure the $\mathrm{pH}$ of each blueberry extract and blueberry wine and titratable acidity (TTA) was determined by titration with $0.1 \mathrm{~N}$ sodium hydroxide solution until $\mathrm{pH} 8.2$ (determined by potentiometric method) and was expressed in terms of citric acid (\%) (Adolfo Lutz Institute 2008). The total sugar content (TSC) was determined by Somogyi (1945) and Nelson (1944) method and alcohol content by Salleron-DuJardin Ebulliometer, with results expressed in degree Gay-Lussac $\left({ }^{\circ} \mathrm{GL}\right)$ (Ribéreau-Gayon et al. 2006).

DETERMINATION OF MONOMERIC ANTHOCYANIN (MA) AND TOTAL ANTHOCYANIN (TA)

Monomeric anthocyanin (MA) and total anthocyanin (TA) content were determined by the pH-differential method (Giusti and Wrolstad 2001). The absorbance was measured at $700 \mathrm{~nm}$ and at the wavelength of maximum absorption. Absorbance $(A)$ was calculated as showed in Equation 1 and monomeric anthocyanins in Equation 2. The total anthocyanins were calculated as showed in Equations 3 and 4. Results were expressed as cyanidin-3-glucoside per one hundred grams of fruit or liter of blueberry wine.

$A=\left(A_{\lambda \max }-A_{700}\right)_{p H 1.0}-\left(A_{\lambda \max }-A_{700}\right)_{p H 4.5}$

Eq. 1

Monomeric Anthocyanins $\left(m g L^{-1}\right)=\frac{A \times M W \times D F \times 1000}{\mathcal{E} \times 1}$

Eq. 2

$A^{\prime}=\left(A_{\lambda \max }-A_{700}\right)_{p H 1.0}$

Total Anthocyanins $\left(m g L^{-1}\right)=\frac{A^{\prime} \times M W \times D F \times 1000}{\mathcal{E} \times 1}$

Eq. 4

Total Flavonol CONTENT AND TOtal PhenOliC CONTENT (TPC)

Total flavonol content was measured by the aluminum chloride colorimetric assay (Zhishen et al. 1999). It was expressed as mg quercetin equivalents $(\mathrm{QE})$ per one hundred grams of fruit or liter of blueberry wine.

The total phenolic content of each extract was determined spectrophotometrically (FEMTO CIRRUS 80ST), according to the Folin-Ciocalteau method (Singleton and Rossi 1965). Absorbance was read at $765 \mathrm{~nm}$ and results were expressed in gallic acid equivalents (GAE) per one hundred grams of fruit or liter of blueberry wine. 


\section{ANTIOXIDANT ACTIVITY}

\section{DPPH method}

DPPH radical scavenging activity was determined according to the method of Brand-Williams et al. (1995) with minor modifications. An aliquot of $3.9 \mathrm{~mL}$ of DPPH solution was mixed with $0.1 \mathrm{~mL}$ of the diluted samples $(1: 50 \mathrm{v} / \mathrm{v})$ at three different concentrations and the absorbance was measured at $517 \mathrm{~nm}$ after $24 \mathrm{~h}$ in the dark. The scavenging effect (\%) was estimated based on the percentage of DPPH radical scavenged as showed in Equation 5:

Scavenging effect $(\%)=\frac{(\text { control abs })-(\text { sampleabs })}{(\text { control abs })} \times 100$

The effective concentration of sample required to scavenge DPPH radical in $50 \%\left(\mathrm{EC}_{50}\right.$ value $)$ was obtained by linear regression analysis, where concentration of sample were plotted against the percentages of DPPH radical scavenged. The lower $\mathrm{EC}_{50}$ means the higher antioxidant activity.

\section{Frap method}

To prepare the FRAP reagent, $200 \mathrm{~mL}$ of acetate buffer $(0.3 \mathrm{M}, \mathrm{pH} 3.6)$ were mixed with $20 \mathrm{~mL}$ of $\mathrm{FeCl}_{3} \cdot 6 \mathrm{H}_{2} \mathrm{O} 20 \mathrm{mM}$ and $20 \mathrm{~mL}$ of TPTZ $(10 \mathrm{mM}$ dissolved in $\mathrm{HCl} 40 \mathrm{mM})$. Aliquots $(0.2 \mathrm{~mL})$ of diluted extracts were mixed with $1.8 \mathrm{~mL}$ of FRAP reagent and the absorbance of the reaction mixture was measured at $593 \mathrm{~nm}$ after incubation at $37^{\circ} \mathrm{C}$ for $10 \mathrm{~min}$ (Benzie and Strain 1996).

\section{SENSORIAL ANALYSIS}

For sensory analysis an ordering test was carried out with twenty assessors who are wine consumers. $\mathrm{T}$ he assessors evaluated the samples for color and flavor. Five samples at $15 \pm 2{ }^{\circ} \mathrm{C}$ were presented to assessors to be organized from the most preferred to the least preferred. The results were calculated by the sum of each sample ordering and were statistically evaluated by Friedman's test at 5\% critical value using data from Newell and MacFarlane (1987) table (AOAC 1995). The research protocol was previously approved by the local Research Ethics Committee (16587313.5.0000.5346) and all the panelists gave their informed consent prior to the inclusion in the study.

\section{STATISTICAL ANALYSIS}

All analyses were carried out in triplicate and the results expressed as mean \pm standard deviation (SD). Statistical analysis was carried out using the Statistica software package version 9.0 (StatSoft, Inc., Tulsa, OK, USA). Differences between means were first analyzed using the one-way ANOVA test and then by the post-hoc Tukey test $(p<0.05)$. Pearson's correlation coefficient was calculated using the Statistic software.

\section{RESULTS AND DISCUSSION}

Chemical Composition of George, Aliceblue And Climax BlueberRies

The physical and chemical characteristics of the studied cultivars are presented in Table I. 
TABLE I

Chemical composition of selected cultivars of blueberry fruit from Itaara - RS.

\begin{tabular}{lccc}
\hline & \multicolumn{3}{c}{ Cultivar } \\
\hline TTA $\left(\right.$ g citric acid $\left.100 \mathrm{~g} \mathrm{~g}^{-1}\right)$ & George & Aliceblue & Climax \\
pH & $0.9 \pm 0.0^{\mathrm{a}}$ & $0.5 \pm 0.0^{\mathrm{c}}$ & $0.6 \pm 0.0^{\mathrm{b}}$ \\
TSS ( ${ }^{\circ}$ Brix) & $2.7 \pm 0.0^{\mathrm{b}}$ & $3.2 \pm 0.1^{\mathrm{a}}$ & $3.2 \pm 0.1^{\mathrm{a}}$ \\
Total sugar $(\%)$ & $12.9 \pm 0.1^{\mathrm{b}}$ & $12.3 \pm 0.3^{\mathrm{b}}$ & $17.6 \pm 0.2^{\mathrm{a}}$ \\
TA $^{1}$ & $10.4 \pm 0.3^{\mathrm{b}}$ & $10.2 \pm 2.9^{\mathrm{b}}$ & $14.0 \pm 1.3^{\mathrm{a}}$ \\
MA $^{2}$ & $76.6 \pm 20.9^{\mathrm{c}}$ & $117.1 \pm 24.2^{\mathrm{b}}$ & $320.3 \pm 19.8^{\mathrm{a}}$ \\
Flavonols $^{3}$ & $75.9 \pm 5.4^{\mathrm{c}}$ & $116.0 \pm 7.3^{\mathrm{b}}$ & $319.4 \pm 5.9^{\mathrm{a}}$ \\
TPC $^{4}$ & $356.8 \pm 30.7^{\mathrm{b}}$ & $302.9 \pm 54.8^{\mathrm{b}}$ & $594.9 \pm 24.6^{\mathrm{a}}$ \\
DPPH $^{\mathrm{b}}\left(\mathrm{EC}_{50}\right)^{5}$ & $390.3 \pm 34.9^{\mathrm{b}}$ & $432.0 \pm 42.3^{\mathrm{b}}$ & $678.4 \pm 60.0^{\mathrm{a}}$ \\
FRAP $^{6}$ & $64.2 \pm 13.9^{\mathrm{a}}$ & $58.1 \pm 12.2^{\mathrm{a}}$ & $21.1 \pm 2.5^{\mathrm{b}}$ \\
\hline
\end{tabular}

Treatment means of the ANOVA test (values are the mean value of three replicates). Values followed by the same letter at same line were not significantly different $(p<0.05)$ by Tukey's test. TTA= Total titratable acid, $\mathrm{TSS}=$ Total soluble solids, $\mathrm{TA}=$ Total Anthocyanin, $\mathrm{MA}=$ Monomeric Anthocyanin, $\mathrm{TPC}=$ Total Phenolic Content $\left({ }^{1,2} \mathrm{mg}\right.$ cyanidin-3-glucoside equivalent $100 \mathrm{~g}^{-1} \mathrm{FW},{ }^{3} \mathrm{mg}$ quercetin-3rutinoside equivalent $100 \mathrm{~g}^{-1} \mathrm{FW},{ }^{4} \mathrm{mg}$ of galic acid equivalent $100 \mathrm{~g}^{-1} \mathrm{FW},{ }^{5} \mathrm{mg} \mathrm{FW},{ }^{6} \mathrm{mg}$ trolox $100 \mathrm{~g}^{-1}$ FW.

The cultivar George showed the highest TTA and the lowest $\mathrm{pH}$ value compared to the other two cultivars (Table I). These characteristics could be related to the composition of organic acid content. Ehlenfeldt and Meredith (1994) show that the predominant organic acid in the highbush (Vaccinium corymbosum L.) cultivars was citric acid, while in rabbiteye (V. ashei Reade) cultivars, succinic and malic acid were found in greater quantities. These authors also showed that in Climax cv., these acids were present at an average level of $89 \%$.

The highest TSS and total sugar content was detected in 'Climax', suggesting that the cultivar was more mature at the same time of harvest. Antunes et al. (2008) reported lower values to the same cultivar (12.81 ${ }^{\circ}$ Brix). Other studies related significant differences in the soluble solids content, titratable acids and sugar content among different blueberry varieties. The values range from 8.5 to $13.32{ }^{\circ} \mathrm{Brix}, 0.4$ to $1.2 \%$

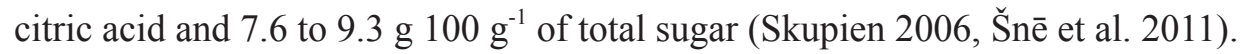

In this study Climax cv. showed the highest content of total phenolics, flavonols and anthocyanins. However, there were no significant differences in total flavonol and total phenolic content among 'George' and 'Aliceblue' $(p<0.05$, Table I). The monomeric anthocyanin content ranged from 75.9 to $319.4 \mathrm{mg}$ cyanidin-3-glucoside per $100 \mathrm{~g} \mathrm{FW}$, while the content of total anthocyanin ranged from 76.6 to $320.4 \mathrm{mg}$ per 100 g FW (Table I). These values represent between 19\% and 47\% of total polyphenols, similarly as described by Bunea et al. (2011), who reported that anthocyanins represented between $23 \%$ and $37 \%$ percent of total polyphenols. The highest total phenolic content was recorded in 'Climax', at $678.4 \mathrm{mg}$ GAE $100 \mathrm{~g}^{-1}$ FW (Table I). Similar values were reported by Rodrigues et al. (2011) in the same cultivar. Nevertheless, Vizzoto et al. (2012) related that the cultivar 'Aliceblue' has higher phenolic content than 'Climax'. Among cultivars, a large variation was also observed from other researchers (167.6 - $677.8 \mathrm{mg}$ cyanidin-3-glucoside per $100 \mathrm{~g} \mathrm{FW}$ ) (Kim et al. 2013). The total anthocyanins and phenolic content of blueberries are higher than other berries but similar to blackberry and elderberry (Nile and Park 2013). 
The genus Vaccinium, member of the family Ericaceae, presents as the main phenolics the group of flavonols (lingonberry and cranberry) and hydroxycinnamic acids (blueberries and bilberry) (Häkkinen et al. 1999). In this study, the content of flavonols represents from $70 \%$ to $91 \%$ of total phenolic content (Table I).

The cultivar Climax exhibited significantly higher antioxidant activity (i.e. lower EC50 values) by DPPH method; however, it does not demonstrate statistical difference when analyzed by FRAP method (Table I).

The great antioxidant activity is in accordance with the high content of total phenolic (coefficient correlation $=0.999)$. Likewise Bunea et al. $(2011)$, our results showed higher correlation between DPPH assay and phenolic content. All differences related about characteristics of cultivars as mentioned by different works occur probably due to different extraction methods, environmental growing conditions, and genotypes.

\section{FERMENTATION OF BLUEBERRIES}

Blueberry wines from all cultivars and treatments were tested periodically for ${ }^{\circ}$ Brix. Figure 1 shows the decline of TSS during fermentation and reveals that the fermentation process occurs quickly until the $12^{\text {th }}$ day and practically stagnates until the $30^{\text {th }}$ day.
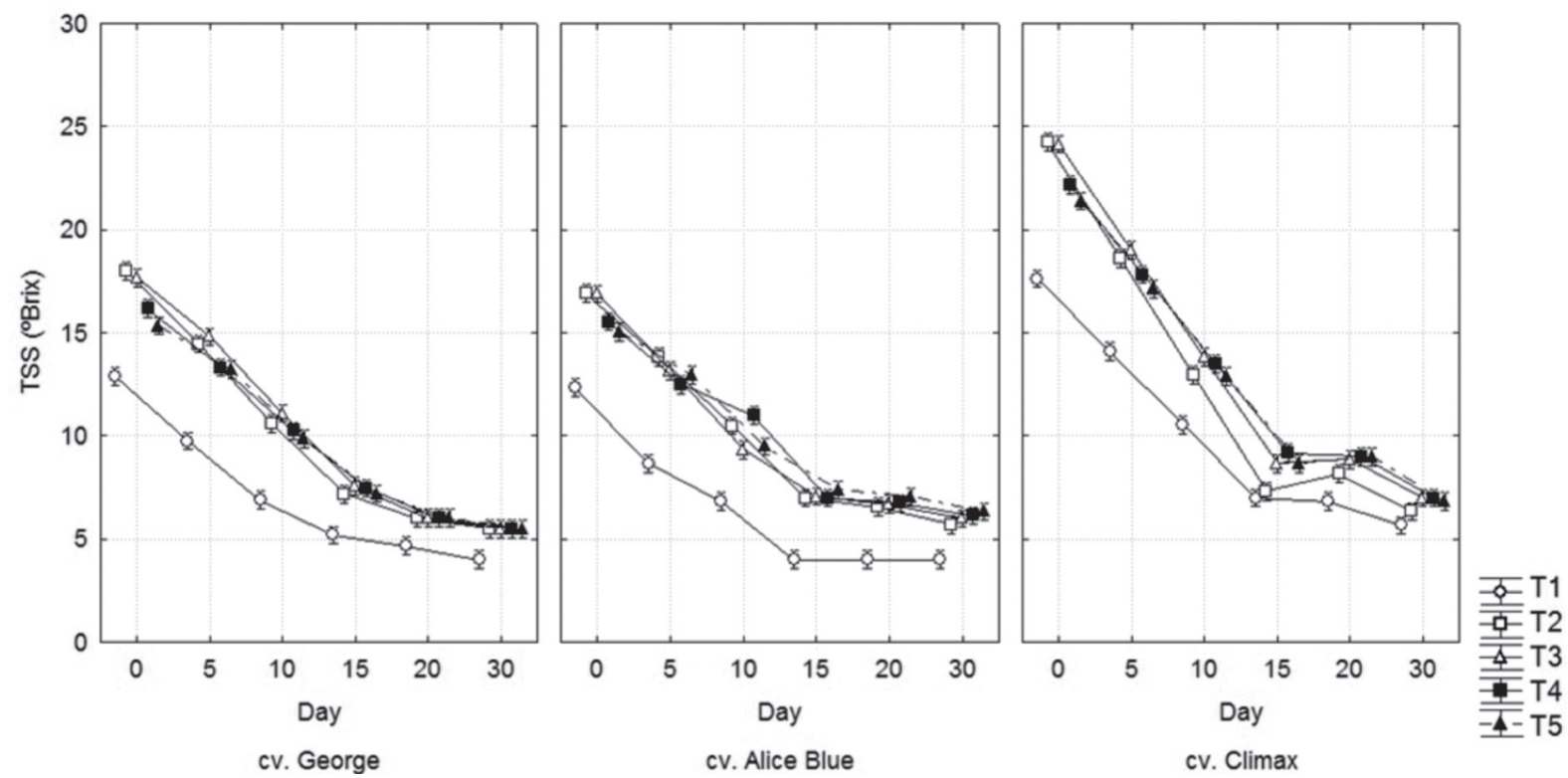

Figure 1 - Fermentation curves for each type of wine throughout time. (T1) control - without sucrose and $\mathrm{CaCO}_{3}$, (T2) sucrose $+0.9 \mathrm{gL}^{-1} \mathrm{CaCO}_{3}$, (T3) sucrose $+1.8 \mathrm{gL}^{-1} \mathrm{CaCO}_{3}$, (T4) glucose syrup $+0.9 \mathrm{gL}^{-1} \mathrm{CaCO}_{3}$, (T5) glucose syrup $+1.8 \mathrm{gL}^{-1} \mathrm{CaCO}_{3}$.

Fruits rich in sugars are preferred for fermentation processes because they provide higher alcohol content, contribute to the texture and make the drink more pleasant to taste (Hashizume 2001). The difference observed among cultivars could be due to different initial sugar content in blueberries used or due to an incomplete fermentation, resulting in more residual sugar in the final fermented wine.

\section{PHYSICOCHEMICAL ANALYSIS OF BLUEBERRY WINES}

In Table II, it can be observed that the use of calcium carbonate (T2 - T5) reduced the total titratable acid and increased $\mathrm{pH}$ values of all blueberry wines, except in George cultivar. 
TABLE II

Physicochemical analysis of blueberry wines.

\begin{tabular}{|c|c|c|c|c|c|}
\hline Cultivar & Treatment & $\begin{array}{c}\text { TAA } \\
\left(\text { g citric acid } 100 \mathrm{~mL}^{-1}\right)\end{array}$ & $\mathrm{pH}$ & $\begin{array}{l}\text { Total sugar } \\
\left(\mathrm{g} \mathrm{L}^{-1}\right)\end{array}$ & $\begin{array}{l}\text { Alcohol } \\
\left({ }^{\circ} \mathrm{GL}\right)\end{array}$ \\
\hline \multirow{5}{*}{ George } & $\mathrm{T} 1$ & $2.1 \pm 0.5^{\mathrm{a}}$ & $3.3 \pm 0.2^{\mathrm{a}}$ & $5.5 \pm 0.2^{c}$ & $5.2 \pm 0.6^{b}$ \\
\hline & $\mathrm{T} 2$ & $1.4 \pm 0.1^{\mathrm{b}}$ & $3.6 \pm 0.1^{\mathrm{a}}$ & $3.8 \pm 1.6^{\mathrm{bc}}$ & $7.5 \pm 0.9^{\mathrm{a}}$ \\
\hline & $\mathrm{T} 3$ & $1.5 \pm 0.1^{\mathrm{b}}$ & $3.7 \pm 0.1^{\mathrm{a}}$ & $1.9 \pm 1.6^{\mathrm{b}}$ & $7.2 \pm 0.3^{\mathrm{a}}$ \\
\hline & $\mathrm{T} 4$ & $1.6 \pm 0.1^{\mathrm{b}}$ & $3.8 \pm 0.1^{\mathrm{a}}$ & $6.9 \pm 1.5^{\mathrm{ac}}$ & $6.2 \pm 0.3^{\mathrm{ab}}$ \\
\hline & $\mathrm{T} 5$ & $1.8 \pm 0.4^{\mathrm{b}}$ & $4.0 \pm 0.1^{\mathrm{a}}$ & $10.1 \pm 1.0^{\mathrm{a}}$ & $5.6 \pm 0.4^{\mathrm{b}}$ \\
\hline \multirow{5}{*}{ Aliceblue } & $\mathrm{T} 1$ & $1.7 \pm 0.1^{\mathrm{a}}$ & $3.5 \pm 0.0^{b}$ & $1.7 \pm 1.7^{\mathrm{c}}$ & $3.8 \pm 0.4^{\mathrm{b}}$ \\
\hline & $\mathrm{T} 2$ & $1.5 \pm 0.1^{\mathrm{ab}}$ & $4.0 \pm 0.1^{\mathrm{a}}$ & $3.1 \pm 1.7^{\mathrm{c}}$ & $7.2 \pm 0.4^{\mathrm{a}}$ \\
\hline & $\mathrm{T} 3$ & $1.3 \pm 0.3^{\mathrm{ab}}$ & $4.1 \pm 0.1^{\mathrm{a}}$ & $5.5 \pm 1.2^{\mathrm{bc}}$ & $7.4 \pm 0.2^{\mathrm{a}}$ \\
\hline & $\mathrm{T} 4$ & $1.2 \pm 0.1^{\mathrm{b}}$ & $3.9 \pm 0.2^{\mathrm{a}}$ & $11.0 \pm 2.6^{\mathrm{a}}$ & $6.0 \pm 0.1^{\mathrm{a}}$ \\
\hline & $\mathrm{T} 5$ & $1.2 \pm 0.5^{b}$ & $4.1 \pm 0.1^{\mathrm{a}}$ & $10.7 \pm 2.5^{\mathrm{ab}}$ & $5.7 \pm 0.6^{\mathrm{a}}$ \\
\hline \multirow{5}{*}{ Climax } & $\mathrm{T} 1$ & $0.9 \pm 0.1^{\mathrm{a}}$ & $3.6 \pm 0.1^{\mathrm{c}}$ & $1.5 \pm 1.9^{c}$ & $7.4 \pm 0.7^{c}$ \\
\hline & $\mathrm{T} 2$ & $0.8 \pm 0.1^{\mathrm{ab}}$ & $3.9 \pm 0.2^{\mathrm{abc}}$ & $2.9 \pm 1.5 b^{b c}$ & $10.8 \pm 0.8^{\mathrm{a}}$ \\
\hline & $\mathrm{T} 3$ & $0.6 \pm 0.1^{\mathrm{b}}$ & $4.2 \pm 0.1^{\mathrm{ab}}$ & $5.5 \pm 4.4^{\mathrm{abc}}$ & $11.1 \pm 0.4^{\mathrm{a}}$ \\
\hline & $\mathrm{T} 4$ & $0.6 \pm 0.1^{\mathrm{b}}$ & $3.8 \pm 0.1^{\mathrm{bc}}$ & $11.5 \pm 1.1^{\mathrm{a}}$ & $9.9 \pm 0.1^{\mathrm{ab}}$ \\
\hline & $\mathrm{T} 5$ & $0.6 \pm 0.1^{\mathrm{b}}$ & $4.3 \pm 0.2^{\mathrm{a}}$ & $9.9 \pm 2.3^{\mathrm{ab}}$ & $9.2 \pm 0.8^{b}$ \\
\hline
\end{tabular}

'(T1) control - without sucrose and $\mathrm{CaCO}_{3}$, (T2) sucrose $+0.9 \mathrm{gL}^{-1} \mathrm{CaCO}_{3}$, (T3) sucrose $+1.8 \mathrm{gL}^{-1} \mathrm{CaCO}_{3}$, (T4) glucose syrup $+0.9 \mathrm{gL}^{-1} \mathrm{CaCO}_{3}$, (T5) glucose syrup $+1.8 \mathrm{gL}^{-1} \mathrm{CaCO}_{3}$ Treatment means of the ANOVA test (values are the mean value of three replications). Values followed by the same letter, within the same column, were not significantly different $(p<0.05)$ by Tukey's test, at the same cultivar. TTA $=$ Total titratable acid.

Possibly George cultivar has a high content of malic acid which, combined with calcium carbonate during fermentation process, resulted in calcium malate. This salt needs at least six months for precipitation and reduction of the total acid content and increase of $\mathrm{pH}$. In addition, wines from Aliceblue and Climax cultivars showed similar $\mathrm{pH}$ values.

These characteristics could be related to the composition of organic acid content and to the high content of potassium in berries. Ehlenfeldt and Meredith (1994) show that the predominant organic acid in the highbush (Vaccinium corymbosum L.) cultivars was citric acid, while in rabbiteye ( $V$. ashei Reade) cultivars, succinic and malic acid were found in greater quantities. These authors also showed that in Climax cv., these acids were present at an average level of $89 \%$.

The low acid content and high $\mathrm{pH}$ value observed in wines from Climax cv. can be due to a content of potassium, which may have contributed to high $\mathrm{pH}$ values without interfering on acid content. In grapes, it was observed that an increase of $\mathrm{pH}$ values is associated with high potassium content, resulting in wines with high $\mathrm{pH}(>3.7)$, on the other hand, it was also observed that $\mathrm{pH}$ is reduced during stabilization (Fogaça et al. 2007). High levels of $\mathrm{pH}$ can decrease the intensity of the color and the stability of wine (Daudt and Fogaça 2008).

The use of glucose (T4 - T5) resulted in wines with more amounts of residual sugar and low alcohol content (Table II). Polakowski (2008) related that yeast had the highest carbon dioxide formation rates using sucrose than all the other sugars studied. Although glucose syrup is composed primarily by glucose and water, it may contain some maltose or other sugars, and vanilla flavoring or preservatives that can affect fermentation. 
TOTAL AND MONOMERIC ANTHOCYANIN, TOTAL FLAVONOLS, PHENOLIC CONTENT AND ANTIOXIDANT CAPACITY OF BLUEBERRY WINES

Phenolic compounds and antioxidant activity presented by blueberry wines can be observed in Table III.

About total phenolic content, researchers have shown that blueberry wine has some similarity with grape wine and has more antioxidants than many fruit wine (Rupasinghe and Clegg 2007). The total phenolic content of George cv. wine does not show a significant difference between treatments, but in wines from Aliceblue and Climax cultivars, higher doses of calcium carbonate increased these values (Table III). Once anthocyanins are part of phenolic content, this increase can be related to high anthocyanin values. Using a similar method of vinification, $\mathrm{Su}$ and Chien (2007) reported lower values of both anthocyanins as total phenolic in blueberry wines $(99.6 \pm 0.11 \mathrm{mg}$ of cyanidin-3-glucoside equivalents per liter and $1150 \pm$ $3.06 \mathrm{mg}$ gallic acid equivalents per liter of sample, respectively). Johnson et al. (2011) also reported lower values of phenolic content (590.0 $\pm 26.7 \mathrm{mg}$ gallic acid equivalents (GAE) per liter of wine).

The blueberries wine from Climax and Aliceblue cultivars showed higher anthocyanin content when elaborated with glucose syrup. Although no significant difference had been observed in 'George', high values of anthocyanin were observed in blueberry wines with more residual sugar. Other approaches also showed that anthocyanin degradation decreased when sucrose concentration increased (Tsai et al. 2004) and in moderate concentration, sugar can preserve the berries anthocyanin (Nikkhah et al. 2007). Normally, anthocyanins seem to be more stable in acidic media at lower $\mathrm{pH}$ values than in alkaline solutions (He et al. 2012). Nevertheless, in this study no significant difference between doses of calcium carbonate was observed.

TABLE III

Total and monomeric anthocyanin, total flavonols, phenolic content, and antioxidant capacity of blueberry wines.

\begin{tabular}{|c|c|c|c|c|c|c|c|}
\hline Cultivar & Treatment & $\mathrm{TA}^{1}$ & $\mathrm{MA}^{2}$ & Total Flavonols $^{3}$ & $\mathrm{TPC}^{4}$ & $\mathrm{DPPH}^{5}$ & FRAP $^{6}$ \\
\hline \multirow{5}{*}{ George } & $\mathrm{T} 1$ & $110.5 \pm 5.5^{\mathrm{a}}$ & $57.8 \pm 12.3^{\mathrm{a}}$ & $1384.6 \pm 348.0^{b}$ & $1883.1 \pm 158.1^{\mathrm{a}}$ & $3.7 \pm 1.3^{c}$ & $23.7 \pm 1.6^{\mathrm{a}}$ \\
\hline & $\mathrm{T} 2$ & $105.6 \pm 16.0^{\mathrm{a}}$ & $65.1 \pm 8.8^{\mathrm{a}}$ & $1450.4 \pm 200.0^{\mathrm{ab}}$ & $1939.5 \pm 60.7^{\mathrm{a}}$ & $4.7 \pm 0.4^{\mathrm{bc}}$ & $23.1 \pm 0.6^{\mathrm{a}}$ \\
\hline & $\mathrm{T} 3$ & $92.7 \pm 15.2^{\mathrm{a}}$ & $55.0 \pm 9.6^{\mathrm{a}}$ & $1779.2 \pm 32.9^{\mathrm{ab}}$ & $1877.5 \pm 173.2^{\mathrm{a}}$ & $5.7 \pm 0.8^{\mathrm{ab}}$ & $22.6 \pm 2.6^{\mathrm{a}}$ \\
\hline & $\mathrm{T} 4$ & $105.6 \pm 6.9^{\mathrm{a}}$ & $69.9 \pm 1.7^{\mathrm{a}}$ & $2042.3 \pm 205.4^{\mathrm{a}}$ & $1947.0 \pm 53.2^{\mathrm{a}}$ & $4.8 \pm 0.6^{\mathrm{abc}}$ & $22.3 \pm 0.7^{\mathrm{a}}$ \\
\hline & $\mathrm{T} 5$ & $86.6 \pm 6.7^{\mathrm{a}}$ & $54.1 \pm 6.2^{\mathrm{a}}$ & $1275.0 \pm 305.6^{\mathrm{b}}$ & $1862.0 \pm 96.1^{\mathrm{a}}$ & $6.4 \pm 0.5^{\mathrm{a}}$ & $23.7 \pm 0.5^{\mathrm{a}}$ \\
\hline \multirow{5}{*}{ Aliceblue } & $\mathrm{T} 1$ & $129.0 \pm 24.0^{b}$ & $69.4 \pm 25.3^{\mathrm{c}}$ & $2141.0 \pm 131.5^{\mathrm{a}}$ & $1676.6 \pm 15.1^{\mathrm{b}}$ & $5.7 \pm 0.6^{\mathrm{a}}$ & $22.9 \pm 3.1^{\mathrm{a}}$ \\
\hline & $\mathrm{T} 2$ & $143.9 \pm 22.2^{\mathrm{ab}}$ & $87.1 \pm 22.4^{\mathrm{cb}}$ & $2162.9 \pm 68.5^{\mathrm{a}}$ & $1752.9 \pm 23.4^{\mathrm{ab}}$ & $6.4 \pm 0.2^{\mathrm{a}}$ & $17.9 \pm 0.1^{\mathrm{a}}$ \\
\hline & $\mathrm{T} 3$ & $152.0 \pm 14.0^{\mathrm{ab}}$ & $96.9 \pm 11.7^{\mathrm{abc}}$ & $1921.7 \pm 242.4^{\mathrm{a}}$ & $1797.8 \pm 83.7^{\mathrm{ab}}$ & $6.3 \pm 1.2^{\mathrm{a}}$ & $19.9 \pm 0.7^{\mathrm{a}}$ \\
\hline & $\mathrm{T} 4$ & $188.1 \pm 6.1^{\mathrm{a}}$ & $128.4 \pm 9.9^{\mathrm{ab}}$ & $1801.1 \pm 214.0^{\mathrm{a}}$ & $1803.1 \pm 36.3^{\mathrm{ab}}$ & $5.3 \pm 0.9^{\mathrm{a}}$ & $20.8 \pm 2.0^{\mathrm{a}}$ \\
\hline & $\mathrm{T} 5$ & $186.6 \pm 15.7^{\mathrm{a}}$ & $134.0 \pm 11.1^{\mathrm{a}}$ & $1142.3 \pm 323.7^{\mathrm{b}}$ & $1899.2 \pm 104.7^{\mathrm{a}}$ & $5.3 \pm 0.8^{\mathrm{a}}$ & $21.9 \pm 4.3^{\mathrm{a}}$ \\
\hline \multirow{5}{*}{ Climax } & $\mathrm{T} 1$ & $108.0 \pm 18.0^{\mathrm{cb}}$ & $54.7 \pm 7.5^{b}$ & $1187.3 \pm 230.2^{\mathrm{b}}$ & $1672.2 \pm 124.9^{\mathrm{d}}$ & $5.4 \pm 0.7^{\mathrm{a}}$ & $19.7 \pm 0.9^{b}$ \\
\hline & $\mathrm{T} 2$ & $105.9 \pm 8.2^{c}$ & $59.3 \pm 4.0^{\mathrm{b}}$ & $1384.6 \pm 484.4^{\mathrm{ab}}$ & $2094.6 \pm 65.0^{c}$ & $4.4 \pm 1.0^{\mathrm{ab}}$ & $20.7 \pm 0.9^{b}$ \\
\hline & $\mathrm{T} 3$ & $139.6 \pm 8.0^{b}$ & $82.8 \pm 5.0^{b}$ & $1845.0 \pm 301.4^{\mathrm{ab}}$ & $2580.2 \pm 96.0^{\mathrm{ab}}$ & $3.3 \pm 0.1^{\mathrm{b}}$ & $32.4 \pm 1.2^{\mathrm{a}}$ \\
\hline & $\mathrm{T} 4$ & $212.5 \pm 11.5^{\mathrm{a}}$ & $123.0 \pm 26.2^{\mathrm{a}}$ & $2130.0 \pm 958.4^{\mathrm{ab}}$ & $2519.4 \pm 111.8^{\mathrm{b}}$ & $3.6 \pm 0.1^{b}$ & $28.8 \pm 0.6^{\mathrm{a}}$ \\
\hline & $\mathrm{T} 5$ & $213.2 \pm 12.8^{\mathrm{a}}$ & $123.3 \pm 15.5^{\mathrm{a}}$ & $2689.0 \pm 189.9^{\mathrm{a}}$ & $2824.6 \pm 54.1^{\mathrm{a}}$ & $3.3 \pm 0.0^{\mathrm{b}}$ & $32.1 \pm 3.8^{\mathrm{a}}$ \\
\hline
\end{tabular}

(T1) control - without sucrose and $\mathrm{CaCO}_{3}$, (T2) sucrose $+0.9 \mathrm{gL}^{-1} \mathrm{CaCO}_{3}$, (T3) sucrose $+1.8 \mathrm{gL}^{-1} \mathrm{CaCO}_{3}$, (T4) glucose syrup + $0.9 \mathrm{gL}^{-1} \mathrm{CaCO}_{3}$, (T5) glucose syrup $+1.8 \mathrm{gL}^{-1} \mathrm{CaCO}_{3}$. Treatment means of the ANOVA test (values are the mean value of three replications). Values followed by the same letter, within the same column, were not significantly different $(p<0.05)$ by Tukey's test, at the same cultivar. TA $=$ Total Anthocyanin, MA= Monomeric Anthocyanin, TPC $=$ Total Phenolics Content. ${ }^{1,2}$ mg cyanidin3 - glucoside equivalent $\mathrm{mg} \mathrm{L}^{-1},{ }^{3} \mathrm{mg}$ quercetin-3-rutinoside equivalent $\mathrm{mg} \mathrm{L}^{-1},{ }^{4} \mathrm{mg}$ of galic acid equivalent $\mathrm{mg} \mathrm{L}^{-1},{ }^{5} \mathrm{EC}_{50},{ }^{6} \mathrm{mg}$ trolox $\mathrm{L}^{-1}$. 
Although the content of total anthocyanins, total flavonols, and phenolic compounds in fruits (Table I) was different among cultivars, these values were similar in wines (Table III). Among treatments, little difference was noted. Nevertheless, in George cultivar higher antioxidant activity was observed in wines without calcium carbonate (Table III). The extraction of these compounds depends mainly on the maceration time and temperature, frequency and mode of cap punching, alcohol, and sulfur dioxide levels (Su and Chien 2007). Furthermore, the content of anthocyanins in wines depends also on the extractability from berries to wine (Romero-Cascales and Ortega-Regules 2005) and mechanical proprieties of berry (Zouid et al. 2010).

In blueberries fruits, a significant variation of individual anthocyanins and phenolic compounds between cultivars has been reported (Kim and Um 2011). The differences in antioxidant capacity behavior may be due to a different phenolic profile, once each phenolic compound has its own capacity and rate of scavenging DPPH free radical (Villaño et al. 2007). Chemical structure of flavan-3-ol family shows generally a good antioxidant response towards DPPH radical (Villaño et al. 2007). However, the stability of the monomeric anthocyanins depends on various factors, such as solution composition, $\mathrm{pH}$ value of wine, presence of substances such as ascorbic acid, sugars, sulfites, cofactors, and metallic ions (He et al. 2012). Possibly, this is a reason for $\mathrm{EC}_{50}$ to be greater when treated with calcium carbonate.

CORRELATION COEFFICIENTS (R²) OF TOTAL AND MONOMERIC ANTHOCYANINS, FLAVONOLS, TOTAL PHENOLIC AND ANTIOXIDANT CAPACITY (FRAP AND DPPH)

Table IV presents the correlation coefficients $\left(\mathrm{r}^{2}\right)$, which indicate the possible correlation between polyphenol composition with different antioxidant activity and the correlation of different assays used with each other.

TABLE IV

Correlation coefficients $\left(r^{2}\right)$ of total and monomeric anthocyanins, flavonols, total phenolic and antioxidant capacity (FRAP and DPPH).

\begin{tabular}{|c|c|c|c|c|c|c|}
\hline & Source & $\mathbf{T A}^{1}$ & $\mathbf{M A}^{2}$ & Flavonols $^{3}$ & $\mathbf{T P}^{4}$ & DPPH $^{5}$ \\
\hline \multirow{6}{*}{$\begin{array}{l}\stackrel{0}{0} \\
\dot{0} \\
\dot{0}\end{array}$} & $\mathrm{MA}^{1}$ & 0.40669 & & & & \\
\hline & Flavonols $^{2}$ & 0.036523 & 0.349987 & & & \\
\hline & $\mathrm{TP}^{3}$ & 0.394232 & 0.955746 & 0.302559 & & \\
\hline & $\mathrm{DPPH}^{4}$ & 0.94541 & 0.196271 & 0.004644 & 0.185763 & \\
\hline & FRAP $^{5}$ & 0.00997 & 0.347093 & 0.916761 & 0.362815 & 0.002249 \\
\hline & Source & $\mathbf{T A}^{1}$ & $\mathbf{M A}^{2}$ & Flavonols $^{3}$ & $\mathbf{T P}^{4}$ & $\mathrm{DPPH}^{5}$ \\
\hline \multirow{6}{*}{ 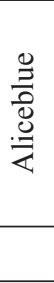 } & $\mathrm{MA}^{1}$ & 0.989116 & & & & \\
\hline & Flavonols $^{2}$ & 0.632727 & 0.70527 & & & \\
\hline & $\mathrm{TP}^{3}$ & 0.732534 & 0.819042 & 0.824352 & & \\
\hline & $\mathrm{DPPH}^{4}$ & 0.461354 & 0.413518 & 0.424763 & 0.157707 & \\
\hline & FRAP $^{5}$ & 0.00789 & 0.005196 & 0.129633 & 0.001019 & 0.526144 \\
\hline & Source & $\mathbf{T A}^{1}$ & $\mathbf{M A}^{2}$ & Flavonols $^{3}$ & $\mathbf{T P}^{4}$ & DPPH $^{5}$ \\
\hline \multirow{5}{*}{ 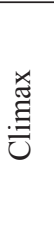 } & $\mathrm{MA}^{1}$ & 0.990947 & & & & \\
\hline & Flavonols $^{2}$ & 0.853037 & 0.880284 & & & \\
\hline & $\mathrm{TP}^{3}$ & 0.63843 & 0.718598 & 0.857705 & & \\
\hline & $\mathrm{DPPH}^{4}$ & 0.508848 & 0.601243 & 0.698608 & 0.959582 & \\
\hline & FRAP $^{5}$ & 0.540208 & 0.61162 & 0.721833 & 0.880132 & 0.879428 \\
\hline
\end{tabular}

$\mathrm{TA}=$ Total Anthocyanin, MA= Monomeric Anthocyanin, $\mathrm{TP}=$ Total Phenolic. 
A correlation analysis was done among total anthocyanins, monomeric anthocyanins, total flavonols, total polyphenols, and the antioxidant activity values obtained. Apparently, high antioxidant activity of blueberry wine from George cv. is related to the presence of total anthocyanins $\left(\mathrm{r}^{2}=0.945\right)$, while blueberry wine from Climax cv. is related to content of total phenolic $\left(\mathrm{r}^{2}=0.959\right)$ by DPPH method. The differences observed are probably associated to composition of antioxidant compounds, once each compound has its own antioxidant activity (Iacopini et al. 2008).

\section{SENSORY ANALYSIS}

Table V shows the differences in the sum of each sample ordering, statistically evaluated by Friedman's test using data from Newell and MacFarlane (1987) table. The results obtained show that the chaptalization with glucose syrup and the reduction of acidity using low dose of calcium carbonate (treatment 4) promoted the highest sum despite the fact that there was no significant statistical difference, suggesting that this combination of chaptalization and deacidification improved the blueberry wine color, independent of the cultivar used (Table V). Interestingly, this treatment was the same with the higher anthocyanin content (Table II), suggesting a relationship between anthocyanin content and preference color by consumer.

TABLE V

Ranking sums of blueberry wine evaluated by the preference test.

\begin{tabular}{ccccccccc}
\hline & \multicolumn{3}{c}{ Color } & & \multicolumn{3}{c}{ Flavor } \\
\cline { 1 - 5 } \cline { 6 - 8 } Treatment Cultivar & George & Aliceblue & Climax & & George & Aliceblue & Climax \\
\cline { 2 - 3 } \cline { 6 - 8 } T1 & $74^{\mathrm{a}}$ & $71^{\mathrm{ab}}$ & $55^{\mathrm{bc}}$ & & $30^{\mathrm{b}}$ & $39^{\mathrm{b}}$ & $58^{\mathrm{a}}$ \\
T2 & $55^{\mathrm{a}}$ & $61^{\mathrm{ab}}$ & $39^{\mathrm{c}}$ & & $62^{\mathrm{a}}$ & $78^{\mathrm{a}}$ & $57^{\mathrm{a}}$ \\
T3 & $45^{\mathrm{b}}$ & $49^{\mathrm{ab}}$ & $49^{\mathrm{bc}}$ & & $63^{\mathrm{a}}$ & $60^{\mathrm{ab}}$ & $54^{\mathrm{a}}$ \\
T4 & $65^{\mathrm{a}}$ & $74^{\mathrm{a}}$ & $88^{\mathrm{a}}$ & & $82^{\mathrm{a}}$ & $56^{\mathrm{ab}}$ & $59^{\mathrm{a}}$ \\
T5 & $61^{\mathrm{a}}$ & $45^{\mathrm{b}}$ & $69^{\mathrm{ab}}$ & & $64^{\mathrm{a}}$ & $66^{\mathrm{ab}}$ & $72^{\mathrm{a}}$ \\
\hline
\end{tabular}

(T1) control - without sucrose and $\mathrm{CaCO}_{3}$, (T2) sucrose $+0.9 \mathrm{gL}^{-1} \mathrm{CaCO}_{3}$, (T3) sucrose $+1.8 \mathrm{gL}^{-1} \mathrm{CaCO}_{3}$, (T4) glucose syrup $+0.9 \mathrm{gL}^{-1} \mathrm{CaCO}_{3}$, (T5) glucose syrup $+1.8 \mathrm{gL}^{-1} \mathrm{CaCO}_{3}$. Values followed by the same letter at the same column were not significant different according to Newell and MacFarlane (1987) table. The critical value for the significance level of $5 \%$ is 28 . The largest sum represents the most preferred.

Regarding flavor, the panelists did not perceive difference in 'Climax' wines. However, in George and Aliceblue cultivars the deacidification and chaptalization also resulted in most favorite wines, and no significant difference was observed among treatments. Our results are similar to other fruit wines. For example, elderberry wines elaborated with low sugar content and high total acidity were the least preferred, while wines with high total sugars and low total acidity were scored as the best for their taste and aroma (Garofulić et al. 2012). Besides improving the color, phenolic compounds may have influenced positively the flavor of wine, once the most preferred wine also contains higher phenolic content (Table II). These compounds can react with salivary proteins in mouth and are responsible for wine astringency and bitterness (Sun et al. 2011). This way, the deacidification with low doses of calcium carbonate and the residual sugar of chaptalization of glucose syrup can be suggested, once panelists demonstrate more preference by this treatment which resulted in wines with more content of anthocyanins comparing to others

\section{CONCLUSIONS}

Based on the results obtained, it can be concluded that calcium carbonate reduces total titratable acidity, while the use of glucose syrup results in blueberry wines with high residual sugar content and low alcohol, 
characteristics that were preferred by panelists in the sensorial analysis. At a first moment, the use of glucose syrup and $0.9 \mathrm{~g} \mathrm{~L}^{-1}$ of calcium carbonate resulted in wines with higher anthocyanins content and a preferred color even though there was no significant differences between treatments in George and Aliceblue cultivars. Regarding the flavor, the blueberry wines from George and Aliceblue cultivars without added sugar and carbonate were the least favorites, while wines with high total sugars and low total acidity had higher approval.

\section{ACKNOWLEDGMENTS}

The authors would like to thank Coordenação de Aperfeiçoamento de Pessoal de Nível Superior (CAPES) for the scholarship to Roberta Santos and to Universidade Federal de Santa Maria (UFSM).

\section{REFERENCES}

ADOLFO LUTZ INSTITUTE. 2008. Métodos físico-químicos para análise de alimentos, 4ª ed., São Paulo, 1020 p.

ALLEMANN L AND YOUNG B. 2006. Fruit \& nut production in Kwazulu-Natal. KZN Agri-Report N/A/2006/24. Cedara, South Africa: KZN Department of Agricultural and Environmental Affairs, 37 p.

ANTUNES LEC, GONÇALVES ED, RISTOW NC AND CARPENEDO S. 2008. Fenologia, produção e qualidade de frutos de mirtilo. Pesqui Agropecuária Bras 43: 1011-1015.

AOAC - ASSOCIATION OF OFFICIAL ANALYTICAL CHEMISTS INTERNATIONAL. 1995. Official methods of analysis. $16^{\text {th }}$ ed., Arlington.

BENZIE IFF AND STRAIN JJ. 1996. The ferric reducing ability of plasma (FRAP) as a measure of “antioxidant power": the FRAP assay. Anal Biochem 239: 70-76.

BRAND-WILLIAMS W, CUVELIER ME AND BERSET C. 1995. Use of a free radical method to evaluate antioxidant activity. Food Sci Technol 28: 25-30.

BUNEAA, RUGINĂ DO, PINTEAAM, BUNEA CI AND SOCACIU C. 2011. Comparative Polyphenolic Content and Antioxidant Activities of Some Wild and Cultivated Blueberries from Romania. Nat Bot Horti Agrobo 39: 70-76.

CASTREJÓN ADR, EICHHOLZ I, ROHNB S, KROHB LW AND HUYSKENS-KEIL S. 2008. Phenolic profile and antioxidant activity of highbush blueberry (Vaccinium corymbosum L.) during fruit maturation and ripening. Food Chem 109: 564-572.

DAUDT CE AND FOGAÇA A DE O. 2008. Efeito do ácido tartárico nos valores de potássio, acidez titulável e pH durante a vinificação de uvas Cabernet Sauvignon. Ciênc Rural 38: 2345-2350.

DHARMADHIKARI M. 1996. Wines from Cherries and Soft Fruits. Vineyard Vintage View 11: 1-9.

EHLENFELDT MK AND MEREDITH FI. 1994. Unique Organic Acid Profile of Rabbiteye vs. Highbush Blueberries. Hort Sci 29: $321-323$.

EHLENFELDT MK AND PRIOR RL. 2001. Oxygen Radical Absorbance Capacity (ORAC) and Phenolic and Anthocyanin Concentrations in Fruit and Leaf Tissues of Highbush Blueberry. J Agric Food Chem 49: 2222-2227.

FACHINELLO JC. 2008. Blueberry. Rev Bras Frutic 30: 285-576.

FOGAÇA O, DAUDT CE AND DORNELES F. 2007. Potássio em uvas II - Análise peciolar e sua correlação com o teor de potássio em uvas viníferas. Food Sci Technol 27: 597-601.

GAROFULIĆ IE, GANIĆ KK, GALIĆ I, DRAGOVIĆ-UZELAC V AND SAVIĆ Z. 2012. The Influence of Processing on Physico-chemical Parameters, Phenolics, Antioxidant Activity and Sensory Attributes of Elderberry (Sambucus nigra L.) Fruit Wine. Croat J Food Technol Biotechnol Nutr 7: 9-13.

GIUSTI MM AND WROLSTAD RE. 2001. Current Protocols in Food Analytical Chemistry. Wrolstad RE, Acree TE, Decker EA, Penner MH, Reid DS, Schwartz SJ, Shoemaker CF, Smith D and Sporns P (Eds), Hoboken, NJ, USA: J Wiley \& Sons, Inc.

HÄKKINEN S, HEINONENC M, KÄRENLAMPID S, MYKKÄNENA H, RUUSKANENE J AND TÖRRÖNEN R. 1999. Screening of selected flavonoids and phenolic acids in 19 berries. Food Res Int 32: 345-353.

HASHIZUME T. 2001. Tecnologia do vinho. In: Aquarone E et al. (Eds), Biotecnologia Industrial: Biotecnologia na produção de Alimentos. São Paulo: Edgard Blücher, p. 21-68.

HE F, LIANG N-N, MU L, PAN Q-H, WANG J, REEVES MJ AND DUAN C-Q. 2012. Anthocyanins and their variation in red wines I. Monomeric anthocyanins and their color expression. Molecules 17: 1571-1601.

IACOPINI P ET AL. 2008. Catechin, epicatechin, quercetin, rutin and resveratrol in red grape: Content, in vitro antioxidant activity and interactions. J Food Comp Anal 21: 589-598. 
ITAARAS'S CITY HALL-RS. 2010. Município de Itaara-RS. Available from: http://www.itaara.rs.gov.br/

JACKSON RS. 2008. Wine Science: Principles and Applications. $3^{\text {rd }}$ ed., Academic Press, 776 p.

JOHNSON MH, LUCIUS A, MEYER T AND DE MEJIA EG. 2011. Cultivar evaluation and effect of fermentation on antioxidant capacity and in vitro inhibition of $\alpha$-amylase and $\alpha$-glucosidase by highbush blueberry (Vaccinium corombosum). J Agric Food Chem 59: 8923-8930.

KIM JG, KIM HL, KIM SJ AND PARK K. 2013. Fruit quality, anthocyanin and total phenolic contents, and antioxidant activities of 45 blueberry cultivars grown in Suwon, Korea. Biomed 14: 793-799.

KIM SM AND UM B-H. 2011. Evaluation of the antioxidant activity of phenolic compounds among blueberry cultivars by HPLCESI / MS and on-line HPLC-ABTS system. J Med Plants Res 5: 5008-5016.

MCGHIE TK AND WALTON MC. 2007. Review The bioavailability and absorption of anthocyanins: Towards a better understanding. Mol Nutr Food Res 51: 702-713.

NELSON N. 1944. A fotometric adaptation of Somogyi method for the determination of glucose. J Biol Chem 153: $375-380$.

NEWELL GJ AND MACFARLANE JD. 1987. Expanded tables for multiple comparison procedure on the analysis of ranked data. J Food Sci 52: 1721-1725.

NIKKHAH E, KHAYAMY M, HEIDARI R AND JAMEE R. 2007. Effect of Sugar Treatment on Stability of Anthocyanin Pigments in Berries. J Biol Sci 7: 1412-1417.

NILE SH AND PARK SW. 2013. Edible berries: Review on bioactive components and their effect on human health. Nutrition 30 : 134-144.

POLAKOWSKI TM. 2008. The effect of different sugars on the rate of fermentation in yeast. Ohio J Sci 108: 30.

RIBÉREAU-GAYON P, GLORIES Y, MAUJEAN A AND DUBOURDIEU D. 2006. Handbook of Enology - Volume 2: The Chemistry of Wine. $2^{\text {nd }}$ ed., J Wiley \& Sons, 450 p.

RIIHINEN K, JAAKOLA LAND KA S. 2008. Organ-specific distribution of phenolic compounds in bilberry (Vaccinium myrtillus) and "northblue" blueberry (Vaccinium corymbosum x V. angustifolium). Food Chem 110: 156-160.

RIZZON LA AND GASPARIN AM. 2005. O carbonato de cálcio na desacidificação do vinho Isabel. Ciênc Rural 35: 720-723.

RODRIGUES E, POERNER N, ROCKENBACH II, GONZAGA LV, MENDES CR AND FETT R. 2011. Phenolic compounds and antioxidant activity of blueberry cultivars grown in Brazil. Food Sci Technol 31: 911-917.

ROMERO-CASCALES I AND ORTEGA-REGULES A. 2005. Differences in Anthocyanin Extractability from Grapes to Wines According to Variety. Am J Enol Vitic 56: 212-219.

RUPASINGHE HPV AND CLEGG S. 2007. Total antioxidant capacity, total phenolic content, mineral elements, and histamine concentrations in wines of different fruit sources. J Food Comp Anal 20: 133-137.

SINGLETON VL AND ROSSI JAJ. 1965. Colorimetry of total phenolics with phosphomolybdic-phosphotungstic acid reagents. Am J Enol Vitic 16: 144-258.

SKUPIEN K. 2006. Chemical composition of selected cultivars of highbush blueberry fruit (Vaccinium corymbosum L.). Folia Hortic 18: 47-56.

ŠNE E, KAMPUSE S AND BERNA E. 2011. The composition of sugars and sugar-acid ratio of highbush blueberry varieties grown in latvia. In Annual $17^{\text {th }}$ International Scientific Conference Proceedings, "Research for Rural development 2011", Jelgava, Latvia 1: 140-144.

SOMOGYI M. 1945. A New Reagent for Determination of Sugars. A new Sugar Reagent. J Biol Chem 160: 6-68.

SU M-S AND CHIEN P-J. 2007. Antioxidant activity, anthocyanins, and phenolics of rabbiteye blueberry (Vaccinium ashei) fluid products as affected by fermentation. Food Chem 104: 182-187.

SUN B, NEVES AC, FERNANDES TA, FERNANDES AL, MATEUS N, DE FREITAS V, LEANDRO C AND SPRANGER MI. 2011. Evolution of phenolic composition of red wine during vinification and storage and its contribution to wine sensory properties and antioxidant activity. J Agric Food Chem 59: 6550-6557.

TSAI P-J, HSIEH Y-Y AND HUANG T-C. 2004. Effect of sugar on anthocyanin degradation and water mobility in a roselle anthocyanin model system using 17O NMR. J Agric Food Chem 52: 3097-3099.

VILLAÑO D, FERNÁNDEZ-PACHÓN MS, MOYÁ ML, TRONCOSO AM AND GARCÍA-PARRILLA MC. 2007. Radical scavenging ability of polyphenolic compounds towards DPPH free radical. Talanta 71: 230-235.

VIZZOTO M, FETTER M DA R, PEREIRA MC AND GONZALES TN. 2012. Bioactive Compounds and Antioxidant Activity of Blueberry (Vaccinium ashei Reade). Acta Hortic 972: 111-115.

ZHISHEN J, MENGCHENG T AND JIANMING W. 1999. The determination of flavonoid contents in mulberry and their scavenging effects on superoxide radicals. Food Chem 64: 555-559.

ZOUID I, SIRET R, MEHINAGIC E, MAURY C AND JOURJON F. 2010. Influence des propriétés mécaniques des baies de Cabernet Franc sur l 'évolution et l' extractibilité des anthocyanes. Rev Suisse Vitic Arboric Hortic 42: 360-366. 